\title{
KEMANDIRIAN PANGAN DENGAN PEMBUATAN BUDIKDAMBER (BUDIDAYA IKAN DALAM EMBER) DI KECAMATAN TELANAIPURA KOTA JAMBI
}

\author{
Deni Irfayanti1*, Putri Wahyu Ningsih2 \\ Fakultas Ekonomi dan Bisnis, Universitas Islam Malang \\ *Korespondensi email: deni.irfayanti@unisma.ac.id
}

\begin{abstract}
ABSTRAK
Kuliah Kerja Nyata Pembelajaran Pemberdayaan Masyarakat (KKN-PPM) KKN Tematik Covid-19 UNISMA merupakan suatu bentuk pendidikan dengan cara memberikan pengalaman belajar kepada mahasiswa sekaligus melatih mahasiwa meningkatkan kapasitas dirinya dengan cara terlibat langsung berperan serta melakukan upaya membantu masyarakat di daerah asalnya masing-masing untuk pencegahan, pemutusan rantai penyebaran Covid-19, meningkatkan ketahanan masyarakat di desanya sendiri untuk siaga, sigap sehingga menjadi desa tangguh menghadapi bencana wabah Covid-19. untuk menjaga ketersediaan atas kebutuhan konsumsi protein keluarga kelas menengah adalah dengan memanfaatkan lahan sempit disekitar rumah/hunian. Terlebih di masa pandemi Covid-19. Dengan cara pembuatan Budikdamber (budidaya ikan dalam ember). Hasilnya dapat dimanfaatkan untuk memenuhi kebutuhan pangan rumah tangga, juga menunjang kondisi ekonomi masyarakat itu sendiri. Program urban farming Budikdamber itu juga sangat cocok diterapkan oleh lintas masyarakat, khususnya bagi mereka yang kesulitan dalam memenuhi kebutuhan pangannya secara mandiri selama pandemi COVID-19 dan memberikan pengalaman baru. Selain bertujuan untuk ketahanan pangan, urban farming juga dapat menguatkan rasa kebersamaan dan menciptakan budaya gotong royong dalam lingkungan masyarakat. Saya berterima kasih dengan adanya program KKN Unisma Malang, karena telah diberi arahan dan tetap bisa produktif dalam memanfaatkan area pekarangan lahan sekitar rumah untuk membuat budikdamber budidaya lele dan menanam sayur kangkung dan lainya yang pasti itu semua dibutuhkan.
\end{abstract}

Kata Kunci: budikdamber; ketahanan pangan.

\section{PENDAHULUAN}

Salah satu program kerja KKN-PPM Tematik kelompok 104 Universitas Islam Malang dalam KKN edisi Covid-19 ini saya membuat program kerja yaitu pembuatan Budikdamber (budidaya ikan dalam ember) di tempat tinggal saya di Kec. Telanaipura Kota Jambi untuk memenuhi kebutuhan pangan dalam keluarga disaat pandemi Covid-19 sekarang ini dengan memanfaatkan pekarangan rumah, sistem kerjanya cukup sederhana. Selain cara kerja yang mudah, bisa mengisi waktu selama adanya penerapan pembatasan sosial akibat wabah virus Corona.

Hasilnya dapat dimanfaatkan untuk memenuhi kebutuhan pangan rumah tangga, juga menunjang kondisi ekonomi masyarakat itu sendiri. Program urban farming Budikdamber itu juga sangat cocok diterapkan oleh lintas masyarakat, khususnya bagi mereka yang kesulitan dalam memenuhi kebutuhan pangannya secara mandiri selama pandemi Covid-19 dan memberikan pengalaman baru. Selain bertujuan untuk ketahanan 
pangan, urban farming juga dapat menguatkan rasa kebersamaan dan menciptakan budaya gotong royong dalam lingkungan masyarakat.

Selain itu dengan adanya KKN-PPM UNISMA ini kami tidak hanya sebagai pengabdian kepada masyarakat tetapi kami juga sebagai potensi untuk memberikan arahan atau solusi pencegahan penularan Covid-19 di Kecamatan Telanaipura Kota Jambi yaitu kami mengadakan kegiatan pembagian masker, pemasangan benner tentang edukasi pencegahan Covid-19, mengedukasi anak-anak dalam belajar daring serta pemahaman mengenai pentingnya mengikuti aturan protokol kesehatan dalam penanggulangan pencegahan Covid19.

\section{METODE}

Kegiatan dilakukan dengan metode mengedukasi masyarakat untuk lebih produktif dengan pembuatan Budikdamber (budidaya ikan dalam ember) dengan memanfaatkan lahan pekarangan rumah, alat dan bahan yang ada disekitar, benih lele, dan menanam kangkung, atau sayuran hidroponik. Wajib menggunakan masker sesuai protokol kesehatan.

\section{HASIL DAN PEMBAHASAN}

Program KKN yang dilakukan mahasiswa UNISMA menerapkan protokol Kesehatan yang sudah di tetapkan oleh pemerintah yaitu jaga jarak dan memakai masker dalam melakukan aktivitas di luar rumah. Adapun program KKN-PPM yang dijalankan pada tanggal 3 Agustus- 3 September 2020.

\section{Identifikasi Masalah}

Dari latar belakang masalah yang ada,program KKN-PPM yang dilakukan berdasarkan klarifikasi yang terdapat pada Tabel 1.

Tabel 1. Program KKN

\begin{tabular}{|c|c|c|c|}
\hline No. & Masalah & Pemecahan Masalah & Bentuk Kegiatan \\
\hline 1. & $\begin{array}{l}\text { Kurangnya perhatian masyarakat } \\
\text { di kecamatan Telanaipura tentang } \\
\text { pencegahan penyebaran Covid-19. }\end{array}$ & $\begin{array}{l}\text { Memberikan penjelasan tentang } \\
\text { bahaya Covid-19 kepada masyarakat } \\
\text { kecamatan telanaipura, dan memberi } \\
\text { edukasi tentang tata cara pencegahan } \\
\text { Covid-19 sesuai dengan anjuran } \\
\text { protokol kesehatan. }\end{array}$ & $\begin{array}{l}\text { Melakukan kegiatan } \\
\text { seperti: } \\
\text { 1. Pembagian Masker } \\
\text { 2. Pemasangan Benner }\end{array}$ \\
\hline 2. & $\begin{array}{l}\text { Disaat pandemi Covid- } 19 \text { seperti ini } \\
\text { banyak masyarakat yang tidak } \\
\text { produktif , kurangnya ketahanan } \\
\text { pangan. }\end{array}$ & $\begin{array}{l}\text { Dengan memanfaatkan lahan di } \\
\text { pekarangan rumah membuat dan } \\
\text { mengedukasi masyarakat untuk } \\
\text { produktif. }\end{array}$ & $\begin{array}{l}\text { Melakukan pembuatan } \\
\text { Budikdamber (budidaya } \\
\text { ikan dalam ember). }\end{array}$ \\
\hline 3. & $\begin{array}{l}\text { Disaat pandemi Covid-19 banyak } \\
\text { sekolah diliburkan dan anak-anak } \\
\text { sekolah online atau belajar daring. } \\
\text { Banyak orangtua yang gak paham } \\
\text { gadget dunia digital. }\end{array}$ & $\begin{array}{l}\text { Mengedukasi anak-anak dan } \\
\text { membantu dalam belajar daring. }\end{array}$ & $\begin{array}{l}\text { Rumah belajar bagi anak- } \\
\text { anak mengerjakan tugas } \\
\text { online. }\end{array}$ \\
\hline 4. & $\begin{array}{l}\text { Adanya pandemi Covid-19 harus } \\
\text { serba bersih mencegah penyebaran } \\
\text { virus. }\end{array}$ & $\begin{array}{l}\text { Dengan membuat cairan disinfektan } \\
\text { untuk mencegah penyebaran virus } \\
\text { Covid-19. }\end{array}$ & $\begin{array}{l}\text { Melakukan Penyemprotan } \\
\text { Disinfektan dilingkungan } \\
\text { tempat tinggal. }\end{array}$ \\
\hline
\end{tabular}

\section{Pelaksanaan Kegiatan}

Pada KKN edisi Covid-19 ini edukasi berfokus pada masyarakat di Kecamatan Telanaipura Kota Jambi. Masyarakat diberikan penjelasan mengenai pemahaman tentang Covid-19 berdasarkan sumber terpercaya, sehingga masyarakat mendapatkan informasi yang bisa diterapkan pada keseharian. Berikut kegiatan kegiatan dari program kerja KKN edisi Covid-19 di Kecamatan Telanaipura, Kota Jambi. 


\section{a. Rumah Belajar anak-anak sekolah daring}

Program kerja di minggu ke-1 yaitu, kegiatan pembelajaran sekolah daring bersama adik-adik sekitar di Kecamatan Telanaipura, Kota Jambi.

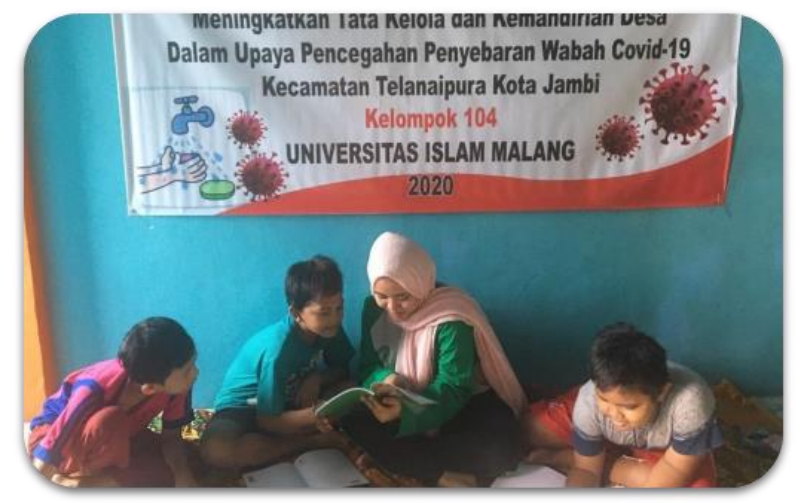

Gambar 1. Rumah Belajar anak-anak sekolah daring

\section{b. Pembagian Masker gratis dan penempelan poster covid-19}

Program kerja Minggu ke-2 yaitu pembagian masker gratis dan penempelan poster covid-19 kepada masyarakat sekitar Kecamatan Telanaipura Kota Jambi sesuai protokol kesehatan.

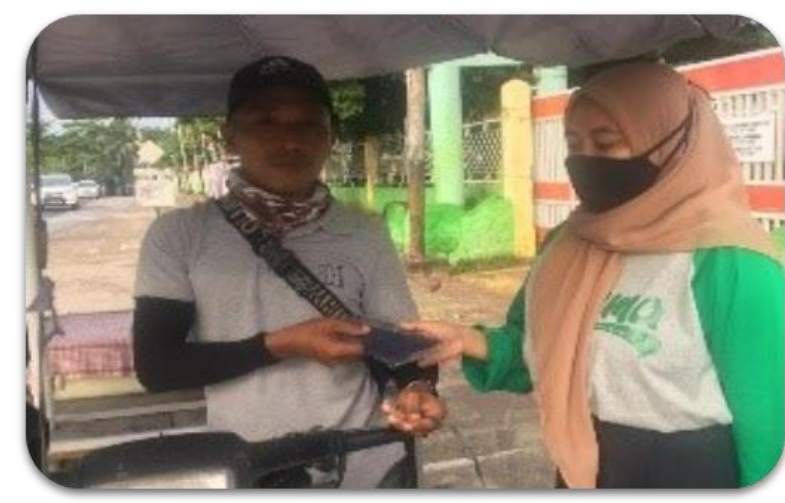

Gambar 2. Pembagian masker gratis

\section{c. Penyemprotan Disinfektan di Lingkungan Tempat Tinggal}

Program kerja minggu ke-3 yang dilakukan yaitu penyemprotan disinfektan di lingkungan tempat tinggal untuk mencegah penularan virus covid-19.

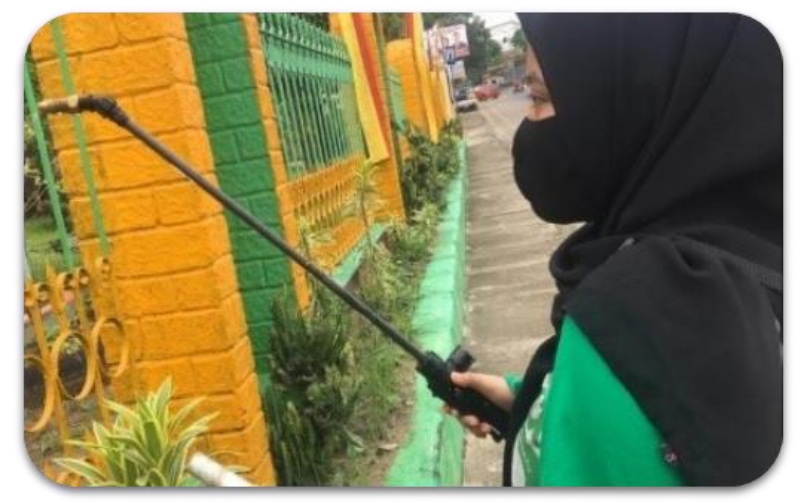

Gambar 3. Penyemprotan Disinfektan di Kec.Telanaipura, Kota Jambi. 


\section{d. Pembuatan Budikdamber (budidaya ikan lele dan kangkung dalam ember)}

Program kerja Minggu-4 yaitu ketahanan pangan dengan pembuatan Budikdamber dengan memanfaatkan lahan di sekitar rumah untuk lebih produktif di kecamatan Telanaipura Kota Jambi.

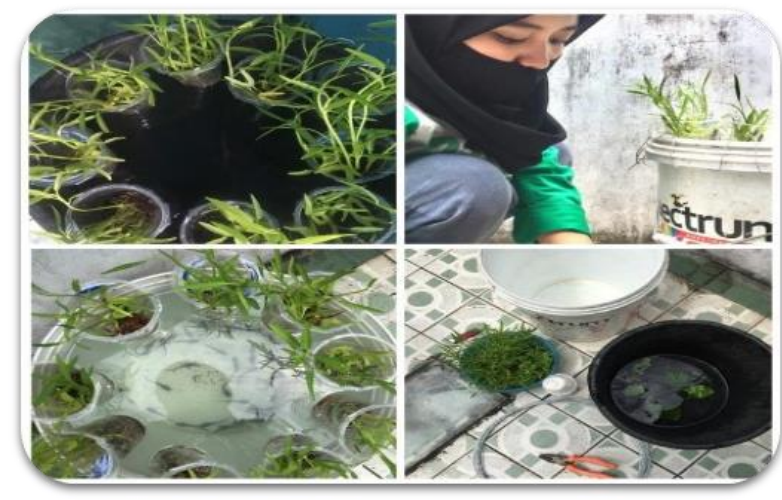

Gambar 4. Pembuatan Budikdamber

\section{Perancangan Desain serta Pembuatan Sistem Budidaya}

Sistem budidaya ikan dalam ember yang dibuat adalah rancangan sistem budidaya yang hemat air dengan menggunakan ember volume 78 liter yang diisi air setinggi $50 \mathrm{~cm}$ atau sebanyak 60 liter air. Pada bagian atas ember digantungkan gelas plastik yang berisi arang kayu sebagai media tanam kangkung aquaponik. Agar tanaman kangkung dapat tumbuh dengan baik maka gelas plastik diberi lubang-lubang kecil sebagai tempat masuknya air ke media tanam kangkung. Luas lahan yang dibutuhkan untuk satu buah media sistem budikdamber ini adalah $0,2 \mathrm{~m} 2$, media ini mampu menampung 60 ekor ikan lele dengan kepadatan 1ekor per liter. Sistem budikdamber yang juga menjadi media tanam kangkung aquaponik di rancang mempunyai kelebihan yaitu tidak membutuhkan listrik seperti yang biasa di gunakan pada sistem resirkulasi aquaponik yang ada di masyarakat. Wadah budidaya ikan yang digunakan mudah didapatkan, hemat dalam penggunaan air serta tambahan penanaman sayuran kangkung untuk memenuhi kebutuhan sayuran.

Selain pelatihan tentang budikdamber, masyarakat juga berkesempatan mendapatkan pelatihan tentang hidroponik sederhana, yaitu budidaya kangkung di dalam baskom. Alat seperti baskom diperoleh dari masyarakat sementara benih kangkung berasal dari tim mahasiswa. Peserta pelatihan sangat antusias karena budidaya kangkung tergolong murah dan mudah diterapkan. Produk yang dibuat objek pelatihan kepada masyarakat selanjutnya diberikan kepada salah satu warga sebagai percontohan yang bertujuan untuk menarik masyarakat lain yang berada di Desa Gending mencoba budidaya ikan dan sayur dalam satu ember serta budidaya kangkung di dalam baskom.

Tahapan membuat Budikdamber:

a. Sediakan gelas untuk tempat bibit kangkung sebanyak 10-15 buah, lubangi dengan solder bawah gelas.

b. Memakai beni kangkung, saya sudah menanam benih terlebih dahulu sampai tumbuh akar dan daun nya, dengan batok kelapa.

c. Potong kawat sepanjang $12 \mathrm{~cm}$ dan buat kait untuk pegangan gelas dalam ember

d. Isi ember dengan air sebanyak 60 liter diamkan selama dua hari

e. Isi ember dengan bibit ikan lele ukuran 5-12 cm sebanyak 60 ekor diamkan selama 1-2 hari 
f. Setelah itu rangkai gelas kangkung dalam ember, rangkai gelas nya kemudian masukan tanaman kangkung nya ke dalam gelas.

Terdapat 2 versi dalam peletakan pot media tanam, yaitu dengan memanfaatkan tutup ember yang dilubangi dan menyambungkan gelas plastik sebagai pot media tanam menggunakan kawat. Kelebihan daripada masing-masing versi rakitan budikdamber adalah penggunaan lebih ekonomis jika menggunakan tutup ember namun populasi gelas plastik sebagai pot media tanam hanya berjumlah 8 lubang. Sementara itu untuk versi yang menggunakan lain kapasitas pot media berjumlah 10-12 pot/ember.

\section{Penebaran Bibit Lele dan Penanaman Sayur}

Persiapan media budikdamber. Ember 80 liter diisi air sampai 60 liter kemudian didiamkan 2 hari untuk mengendapkan air sumur. Gelas plastik diisi arang yang sudah dihancurkan untuk media tanam sayur. Setelah dua hari dilakukan pengisian bibit lele ke dalam ember yang sudah disiapkan serta penanaman kangkung. Setiap ember diisi sekitar 60 ekor bibit lele.. Kontrol kualitas air juga dilakukan setelah penebaran bibit lele agar kualitas air terjaga. Kualitas air yang diamati saat ini adalah kandungan oksigen terlarut dan $\mathrm{pH}$ air.

\section{Kualitas Air Budidaya}

Kualitas air yang diamati selama pelaksanaan kegiatan Budikdamber adalah suhu, pH, DO, Amonia dan kekeruhan. Berdasarkan hasil pengamatan, kualitas air media pemeliharaan masih mendukung untuk kehidupan Ikan Lele. Berikut adalah hasil pengamatan kualitas air Budikdamber.

\section{Pemeliharaan Budikdamber}

Untuk pemeliharaan, letakkan ember di tempat terkena matahari maksimal. Berikan pakan kepada ikan sesuai ukuran sekenyangnya bisa 2-3 kali dengan waktu tetap. Tanaman kangkung akan terlihat tumbuh di hari ke-3. Jangan lupa perhatikan bila ada kutu di daun kangkung, segera buang daun atau batang karena kangkung akan kriting dan mati. Penampakan air akan berubah menjadi warna hijau.

Perlu selalu diperhatikan dan amati nafsu makan ikan setiap hari.Apabila nafsu makan ikan menurun, air berbau busuk (NH3, H2S), ikan menggantung (kepala di atas, ekor ke bawah) segera ganti air atau lakukan sipon (Penyedotan kotoran di dasar ember dengan selang). Ganti air biasanya 10-14 hari sekali. Untuk penyedotan 5-8 liter, bisa lebih atau keseluruhan bila perlu, ganti dengan air bersih. Jika kangkung membesar maka dibutuhkan air lebih banyak, tambahkan air setinggi leher ember.

\section{Waktu Panen Kangkung dan Ikan}

Waktu panen tanaman kangkung pertama adalah 14-21 hari sejak tanam. Saat panen sisakan kembali bagian bawah atau tunas kangkung untuk pertumbuhan kembali. Panen ke-2 dan selanjutnya berjarak 10-14 hari sekali. Panen kangkung bisa bertahan 4 bulan.Untuk waktu panen ikan lele dapat dilakukan dalam 2 bulan, bila benih bagus dan pakan baik. Perlu diketahui tingkat bertahan hidup (survival) ikan lele 40-100 persen.

\section{Kendala yang dihadapi}

Terdapat beberapa kendala yang terjadi seperti tanaman yang mengalami etiolasi (pertumbuhan tinggi tanaman tanpa pertambahan jumlah daun), baik pada budidaya kangkung di dalam baskom maupun tanaman yang beradadi dalam ember budidaya lele sebagai akibat darikurangnya sinar matahari. Sehingga, tanaman dipindahkan di bawah sinar matahari Namun, ikan yang dibudidayakan tumbuh dengan baik karena masyarakat memberi makan setiap hari menggunakan pakan ikan yang sesuai. Kegiatan monitoring tidak dilakukan hingga sayuran dan ikan panen karena keterbatasan waktu. 


\section{Uji Kinerja Sistem Budidaya Ikan Dalam Ember}

Uji kinerja sistem budidaya ikan dalam ember dilakukan selama empat puluh hari. Uji ini dilakukan untuk mengetahui apakah sistem sudah berjalan dengan baik sebagai media untuk tempat hidup ikan dan tempat hidup kangkung aquaponik, serta untuk mengetahui perbaikan apa yang perlu dilakukan. Uji kinerja sistem budidaya ikan dalam ember yang telah dilakukan adalah:

a. Daya tampung ikan yang dapat di pelihara dalam media ember dari ukuran 5-7 hingga benih 11-13 cm adalah 60 ekor, daya dukung ember masih teramati mampu mendukung kehidupan ikan.

b. Uji kinerja sistem ini perlu mendapatkan perbaikan penambahan lubang dipinggir ember untuk menjaga tinggi air agar tidak tumpah keluar ketika hujan.

c. Daya dukung media kangkung akuaponik : Tanaman sayuran yang di tanam di media budikdamber adalah kangkung. Dari uji coba diketahui media gelas yang diberi arang kayu sudah mampu menumbuhkan kangkung dengan baik, namun perlu dicari sayuran lain yang dapat di tanam secara aquaponik di media budikdamber.

d. Pertumbuhan kangkung cukup baik, jarak waktu panen yaitu 10 - 16 hari. Selama 40 hari dapat dilakukan pemanenan kangkung sebanyak 3 kali. Rata-rata satu ember media budikdamber dapat menghasilkan minimal 42 ikat selama 40 hari pemeliharaan.

\section{KESIMPULAN}

Program kerja KKN-Tematik Unisma suatu pembelajaran mahasiswa/i langsung melihat kondisi masyarakat terjun langsung ke lapangan membantu dan menjadikan mahasiswa/i mempunyai rasa tanggung jawab, empati terhadap sesama, mengedukasi menerapkan sesuai keilmuan nya masing-masing dan ikut serta membantu dalam mencegah penyebaran virus covid-19 sesuai protokol kesehatan yang dilakukan kepala desa, RT, RW, satgas covid, dan masyarakat sekitar.

Kegiatan pengabdian masyarakat yang telah dilakukan adalah penyerahan alat dan bahan, pembuatan wadah, penebaran bibit lele dan tanam sayur, sosialisasi serta panen Ikan Lele dan kangkung, pembagian masker, penempelan poster, penyemprotan disinfektan, dan membantu anak-anak belajar daring.

Sistem budidaya ikan lele di media ember 60 liter dapat dijadikan solusi budidaya ikan khususnya di lahan yang sempit. Pemeliharaan selama 42 hari menghasilkan SR ikan lele $41-70 \%$, panen ikan sebanyak 2440 gr (71, 76 gr/ekor), dan panen kangkung yang dihasilkan sebanyak 42 ikat. Namun, hasil tersebut masih perlu dioptimalkan dengan mendesain kembali wadah budidaya agar dapat menghindari kematian akibat predator dan ikan yang lompat keluar wadah.

\section{DAFTAR RUJUKAN}

Kemendikbud. (2020) 'Perluas Akses Belajar di Masa Covid-19, Mendikbud Luncurkan Program Belajar dari Rumah' Kementerian Pendidikan dan Kebudayaan. [online]. https://www.kemdikbud.go.id/main/blog/2020/04/perluas-akses-belajardi-masacovid19-mendikbud-luncurkan-program-belajar-dari-rumah

Nurhalimah, N. (2020). Upaya Bela Negara Melalui Sosial Distancing Dan Lockdown Untuk Mengatasi Wabah Covid-19 (Efforts to Defend the Country Through Social Distancing and Lockdown to Overcome the COVID-19 Plague). Available at SSRN 3576405.

Nursandi. 2018. Budidaya Ikan dalam Ember "Budikdamber" dengan Akuaponik di Lahan Sempit. 